\title{
De bestias, monstruos y príncipes encantados: Una mirada cultural a la adaptación cinematográfica del cuento de la Bella y la Bestia*
}

Recibido: 2015-04-05 -Enviado a pares: 2015-04-11

Aprobado por pares: 2015-05-05 Aceptado: 2015-05-10

Ángela María Rodríguez Marroquín **

\section{Resumen}

Esta investigación ofrecerá una reflexión sobre el uso de los cuentos de hadas como fuente para el historiador, mostrando de esa forma la aproximación que tiene el cuento de la Bella y la Bestia, con los conceptos de la belleza/fealdad y la civilización/barbarie.

Así, el análisis se basará, en la relación que tienen las adaptaciones cinematográficas con dicho cuento; también, podemos observar aquella dicotomía con el lenguaje cinematográfico, donde Bella un personaje civilizador, intenta domar a aquel monstruo (La Bestia).

No obstante, se tomará como base el cuento escrito por Jeanne- Marie LePrince de Beaumont, para mirar cuáles son las características de estas dos dualidades antes mencionadas y, de esa manera, analizar en las adaptaciones cinematográficas que se realizaron en Estados Unidos entre 1960 hasta el 1991, las transformaciones que ha tenido esta historia, para comprender la forma en que la sociedad destaca, en las representaciones de los personajes, las virtudes o los defectos.

Palabras clave: cuentos de hadas, La Bella y la Bestia, adaptación cinematográfica.

Esta investigación hace parte de un estudio realizado en la Maestría sobre la relación del cine y los cuentos de hadas (Colombia)

"* Historiadora y magíster en Historia de la Universidad Nacional de Colombia sede Medellín; actualmente adelanta estudios de Doctorado en Historia en la misma universidad. Miembro del grupo de investigación Historia, Trabajo, Sociedad y Cultura de la línea Historia y Fuentes Audiovisuales. Email: amrodriguezma@ unal.edu.co 


\title{
Of beasts, monsters and charming princes: A cultural look into the cinematographic adaptation of the tale of Beauty and the Beast
}

\begin{abstract}
This research offers a reflection on the use of fairy tales as a source for historians, showing thus the approach to the tale of Beauty and the Beast with the concepts of beauty/ugliness and civilization/barbarism.

Thus, the analysis is based on the relation between the cinematographic adaptations and the original tale. It also presents the cinematographic language dichotomy in which Beauty, a civilized character, tries to tame the monster (Beast).

The study is based on the tale written by Jeanne-Marie Leprince de Beaumont and it is focused on identifying the characteristics of the aforementioned dualities. After identifying the characteristics, the article presents an analysis of the transformations suffered by the story in the cinematographic adaptations produced in the United States between 1960 and 1991 in order to understand the way in which the society highlights the virtues or the defects in the representations of the characters.
\end{abstract}

Key words: fairy tales, Beauty and the Beast, cinematographic adaptation.

\section{De feras, monstros e príncipes encantados: Um olhar cultural na adaptação cinematográfica do conto A Bela e a Fera}

\section{Resumo}

Esta pesquisa vai se concentrar em oferecer uma reflexão sobre o uso de contos de fadas como uma fonte para o historiador; mostrando assim a abordagem que tem a história de A Bela é a Fera, com os conceitos de beleza/feiura e civilização/ barbárie.

Assim, a análise é baseada na relação das adaptações para o cinema com essa história; também podemos ver esta dicotomia com a linguagem do filme, onde Bella um personagem civilizatório tenta domar esse monstro (a Fera).

No entanto, o conto escrito por Jeanne-Marie Leprince de Beaumont, será a base para olhar as características dessas duas dualidades mencionadas e, portanto, analisados nas adaptações para o cinema que foram feitas nos EUA em 1960 até 1991, as mudanças que esta história, para entender como a sociedade representa nos personagens, as virtudes ou defeitos.

Palavras Chave: Contos de fadas, A Fela e a Fera, adaptação para o cinema. 
"El hombre llamado civilizado no ha dado un solo paso sin ir acompañado de su sombra, el salvaje"1.

Roger Bartra

\section{Introducción}

Lo cuentos de hadas han sido estudiados por diversas disciplinas y áreas de investigación; las más conocidas hasta ahora son: la literatura', la psicología ${ }^{2}$, el psicoanálisis ${ }^{3}$, el cine ${ }^{4}$, entre otras. Sin embargo, con el paso del tiempo han surgido algunos estudios que se enfocan en la historia cultural ${ }^{5}$, demostrando todos los elementos que puede tener en este tipo de historias, y cómo observar las distintas reapropiaciones de los cuentos de hadas en distintas épocas, incluso, nos permiten percibir los cambios de una cultura a otra, destacando la configuración cultural, social y económica, las cuales están asociadas a la religión, las prácticas y las costumbres.

Debemos señalar que al analizar las estructuras de los cuentos de hadas, logramos entender los elementos o características con los que estas historias fueron creadas, y cómo estas llegan a permanecer con los años e, incluso, con los siglos. De ese modo, al transformarse los mitos ${ }^{6}$ en los cuentos de hadas, los estereotipos que los narradores utilizaban seguían representando, en la figura del héroe, la hazaña cómo una virtud y, en la del villano, la tiranía cómo un defecto, y todo ello iba vinculado al principio moral de la sociedad que contaba estas historias ${ }^{7}$; así, aquella moraleja o enseñanza de contenido moral y ético que tenían los cuentos de hadas contaba con la función de ilustrar las conductas apropiadas socialmente. Por lo tanto, con estos cuentos se lograban la instrucción y la sociabilización de las normativas de la sociedad, las cuales se relacionaban con el comportamiento, el alma y el cuerpo de la persona ${ }^{8}$.

Propp. V. (1984). Las raíces históricas del cuento. Madrid: Ed. Fundamentos.

2 Rousseau. R. (1994), La otra cara de los cuentos. Valor iniciático y contenido secreto en los cuentos de hadas. Gerona: Tikal Ediciones.

3 Bettlelheim. B (2002) Psicoanálisis de los cuentos de hadas. Barcelona: Crítica.

$4 \quad$ Ver los estudios de Davis. A. (2006) Good Girls \& Wicked Witches. Women in Disney's Feature Animation. Estados Unidos: John Libbey Publiching y Davis. A. (2013) Handsome Heroes \& Vile Villains. Men in Disney's Feature Animation. Estados Unidos: John Libbey Publiching

5 Sobre el tema, revisar estudios como: Darnton, R. (1987). Los campesinos cuentan cuentos: El significado de Mamá Oca. En La gran matanza de los gatos y otros episodios en la historia de la cultura francesa. México: Fondo de Cultura Económica. p. 15-80 y en Ginzburg. C. (1991). Huesos y pieles. En Historia nocturna un desciframiento del aquelarre. España: Muchnik editores S.A. p. 173-213.

6 Antes de que existieran los cuentos de hadas el relato más utilizado era el mito, el cual, ayudaba a transmitir la memoria del hombre, enseñar costumbres y comportamientos sociales. Sin embargo, con la llegada de los cuentos, estos pasaron a ser utilizados, para enseñar los contenidos morales.

7 Ángela María Rodríguez Marroquín; Érase una vez muchas cenicientas: cómo leer el modelo femenino del siglo xx desde las películas norteamericanas de la Cenicienta; Memoria y Sociedad, vol. 16 N. ${ }^{\circ} 33$

8 Para ampliar más sobre el concepto de cuento ejemplarizante "exemplum" ver: Borja Gómez, J. H. (2002) El exemplum en la narración histórica, en Los indios medievales de Fray Pedro de Aguado. Construcción del idólatra y escritura de la historia en una crónica del siglo XVI. Bogotá: CEJA. 
Así, podemos destacar de esa manera, cómo las estructuras de este tipo de relatos pueden ser analizadas, para comprender la forma en que las distintas sociedades plasmaban su pasado, representando en los personajes los vicios de los cuales se debía tomar distancia o las virtudes que se debían seguir. Ahora bien, llevando este modelo moralizador de los cuentos de hadas al cine, podemos observar, que aún guardan mucha relación con los relatos orales elementos como el dualismo de vicio y virtud, para representar el comportamiento socialmente aceptado, y la forma en que los narradores plasman entre líneas, parte de la cultura.

Cabe mencionar que estas estructuras, al ser trasladadas de la fantasía al celuloide, en algunos momentos conservan la estructura del relato original, pero en otrod casos, estas adaptaciones tratan de romper con las convenciones establecidas que existen, para poder lograr la "modernización" 9 de los cuentos de hadas. Por ello, podemos observar cómo cada director de cine emplea en estas nuevas adaptaciones, unos códigos y elementos que le permiten acerarse a la sociedad a la cultura material y a las prácticas de la época en que se crea la película; de esta manera, desde el lenguaje cinematográfico es desde donde se facilita la lectura del comportamiento social.

Así, desde una perspectiva histórica y cinematográfica, este artículo analiza las representaciones del cuento de la Bella y la Bestia, apoyado en siete productos culturales -entre películas y series de televisión-, para realizar desde el lenguaje cinematográfico y los códigos culturales, un acercamiento a una realidad social, sin olvidar que esas imágenes que vemos en la pantalla están mediatizadas por la sociedad y que pueden variar dependiendo de la época o el discurso que posean.

Cabe destacar que los cuentos de hadas, al igual que las películas, le sirven de fuente al historiador, ya que estos abren un abanico de posibilidades y puntos de vista, para estudiar la sociedad y la época en que produjeron esas imágenes; al mismo tiempo, el investigador debe de asumir el papel de traductor, para poder analizar las apropiaciones y adaptaciones que son presentadas en los filmes y así observar cómo es su relación con el pasado, teniendo presente que esas representaciones poseen tanto de realidad como de ficción.

\section{Metodología}

Se realizó una selección de siete películas - entre cortometrajes, mediometrajes y largometrajes- para su posterior análisis y para observar la relación que tienen los comportamientos de los personajes de la Bella y la Bestia, con los aspectos de la belleza/ fealdad y la civilización/barbarie, que se reflejan en la historia original. De ese modo, se utilizará como base el trabajo de Mary Douglas "Los usos de la divulgación: una lectura francesa de Caperucita Roja"10 quien utiliza los conceptos de "representación de la vida

9 Dicha modernización tiene que ver con el uso de elementos paródicos, traducción, adaptación, transformación social y cultural, para poder actualizar el cuento de hadas a la sociedad contemporánea

10 Douglas, M. (1996). "Los usos de la divulgación: una lectura francesa de Caperucita Roja" en Estilos de pensar, España: Gedisa, pp. 19-37 
cotidiana" para observar las prácticas y costumbres de una determinada sociedad, y el de "parodia" para observar los elementos que son utilizados en el cuento, para burlarse de la estructura social.

Asimismo, se utilizarán los métodos de Jack Zipes ${ }^{11}$ y de Lucie Armitt ${ }^{12}$ quienes hablan del carácter intertextual de los cuentos de hadas y de cómo diversas adaptaciones, versiones y traducciones logran destacar elementos como la parodia, la ironía, entre otros, para trabajar la historia cultural de los cuentos de hadas, que nos ayudará a aproximar el análisis de ciertos elementos o características con la cultura y la sociedad norteamericana. Así, estas películas como productos culturales ${ }^{13}$ permiten relacionar la historia con elementos históricos, como los bestiarios, el mito del salvaje y la historia de la familia Gonsalvus; todo ello, con el fin de poder comprender las representaciones que hace la sociedad de acuerdo a las virtudes o los defectos. Y para ello, se tomó el período de tiempo de 1960 que es donde surge el primer cortometraje estadounidense hasta 1991, época en la cual, se estrena la versión de Walt Disney; esto, con el objetivo de comparar cada versión y los elementos del cuento de hadas relacionados con la historia.

\section{De los cuentos de hadas a la pantalla encantada}

Cuando hablamos de la adaptación cinematográfica de un cuento de hadas, debemos tener presente que los directores hacen uso de varios elementos del relato original, para contar desde el lenguaje cinematográfico este cuento de hadas ${ }^{14}$. Así, a diferencia de otros cuentos de hadas que fueron adaptados desde los inicios del cine ${ }^{15}$, esta historia tiene su primera adaptación cinematográfica en 1946 con Jean Cocteau. Al inicio de la película hay un título introductorio o a modo de advertencia, que dice:

Los niños creen lo que les cuentan y no lo ponen en duda. Creen que coger una rosa puede atraer desgracias a una familia. Creen que las manos de una bestia humana asesina echan humo. Y que dicha bestia tiene vergüenza cuando una joven vive en su casa. Creen otras miles de cosas muy ingenuas. Lo que les pido es un poco de esa ingenuidad, y para

1 Zipes, J. (2014), El irresistible cuento de hadas. Historia cultural y social de un género, Buenos Aires: Fondo de Cultura Económica.

12 Armitt, L. (1996) Theorising The Fantastic, Gran Bretaña: Arnold.

13 El lenguaje visual que manejan las películas y los programas de televisión es diferente, pero en este caso, se agrupo para un análisis por igual, para poder detallar las diferentes traducciones, adaptaciones y, de esa manera, mostrar los cambios culturales, la parodia y la ironía, que pueden llegar a manejar algunos de estas versiones.

14 Para ampliar este tema revisar el libro Zipes, J. (2011) The Enchanted Screen: The Unknown History of Fairy-Tale Films. New York. Routledge. Allí, el autor realiza un análisis histórico y literario de diferentes cuentos de hadas, para mostrar los elementos culturales que se observan en las películas y así, señalar la transformación o los pocos cambios que pueden haber entre los distintos filmes.

15 Entre los primeros cuentos adaptados al cine se encuentra el de Cenicienta, ya que, cuenta con dos versiones de Georges Méliès en 1899 y en 1912. Así mismo, este cuento, es a su vez uno de los más adaptados en la historia del cine, ya que posee más de 150 adaptaciones cinematográficas en todo el mundo. 
que nos traiga suerte a todos, dejen que les diga las palabras mágicas, un auténtico "ábrete sésamo" de la infancia... érase una vez...

Con esta premisa, podemos ver que Cocteau utilizará una serie de elementos para mostrar, a su modo, el mágico mundo que rodeará la historia de la Bella y la Bestia. Por ello, es interesante ver la recreación que hace con el personaje de la Bestia, al utilizar como modelo a Petrus Gonzalvus ${ }^{16}$, para representar en el actor Jean Marais, al esposo bestia ${ }^{17}$. Y, además, para recrear la magia que hay en el castillo, según lo muestra el cuento de LePrince, utiliza desde el lenguaje cinematográfico, brazos y manos que se mueven para servir o iluminar a los habitantes del palacio, simbolizando de esa manera el castillo encantado.

De esa forma, no debemos olvidar que parte de este lenguaje cinematográfico que utilizó Cocteau llegó a ser reproducido en varias de las películas de la Bella y la Bestia, en menor o mayor grado, aunque también debemos tener en cuenta que esta iconografía se nutrió de las ilustraciones del cuento y de los bestiarios, para recrear la figura de la Bestia.

Así, en 1976 Fielder Cook estrena la película The Beauty and The Beast, siendo una adaptación que sigue muchos de los elementos del cuento, como los brazos y manos que son los "sirvientes" del castillo, la escena donde Bella espera a la Bestia a comer, entre otros. Sin embargo, una noche mientras la Bella y la Bestia cenan, la Bestia le cuenta a la Bella la historia de la dama y el unicornio.

Así, mientras observamos en un plano medio la curiosidad de la joven (interpretada por Trish Van Devere) por conocer la historia, en un contraplano vemos a la Bestia (interpretado por Georges C. Scott), en el papel de narrador, contando cómo una joven doncella se hizo amiga de un unicornio, y mientras el relato avanza, percibimos las expresiones de los dos personajes en contraplanos; finalmente, en un plano general vemos a la Bestia aproximarse a la chimenea, al mismo tiempo que levanta la mirada hacia un tapiz, para contar que aquel unicornio fue traicionado por la doncella y posteriormente asesinado, en manos de otros hombres; así, en la siguiente escena, observamos en un plano detalle el tapiz de la dama y el unicornio (fig. 1).

Esta metáfora con la historia de la dama y el unicornio tiene muchos simbolismos y, en cierta medida, nos remite a una antigua canción sobre unicornios: "Soy semejante al unicornio,/ Que queda atónito al mirar/ Cuando contempla a la doncella. /Tanto goza con su tormento/ Que cae exánime en su regazo;/ Entonces, lo matan a traición [...] (Malaxecheverría, 1999, p. 197). Así, en la historia que narra la Bestia, apreciamos la gran

16 Petrus Gonsalvus (1537-1618), fue un niño salvaje encontrado en Francia y criado por el rey Enrique II, tras ser instruido y educado con las costumbres sociales, fue instruido en latín y humanidades y, pasó a formar parte de la corte. En 1573, Pretus se casó con Catherine y tiene seis hijos, de los cuales cuatro nacieron con la misma enfermedad que su padre.

17 Cuando recién salió el cuento de la Bella y la Bestia en Francia, las personas supieron inmediatamente, que este hacia una referencia a la historia del hombre velludo (Petrus Gonsalvus) y la dama de compañía de Catalina de Medici, Katerine. Por ello, la bestia de Cocteau, adquiere los rasgos de "salvajes" de este. Para ampliar el tema, ver Manguel, A. (2000), "La imagen como comprensión", en Leyendo imágenes. Una historia privada del arte. Colombia: Editorial Norma, pp.105-136 
ternura que tiene la doncella por esta criatura, mientras que el animal va sintiendo una fuerte atracción hacia ella; por ello, la doncella llega a mimarlo y con el paso del tiempo, puede llegar inclusive a domesticarlo y en cierta forma, el unicornio poco a poco va renunciando a su soledad y sus costumbres para permanecer al lado de la joven (fig. 2). Así, la semejanza que tiene esta historia con la de la Bella y la Bestia es bastante particular.
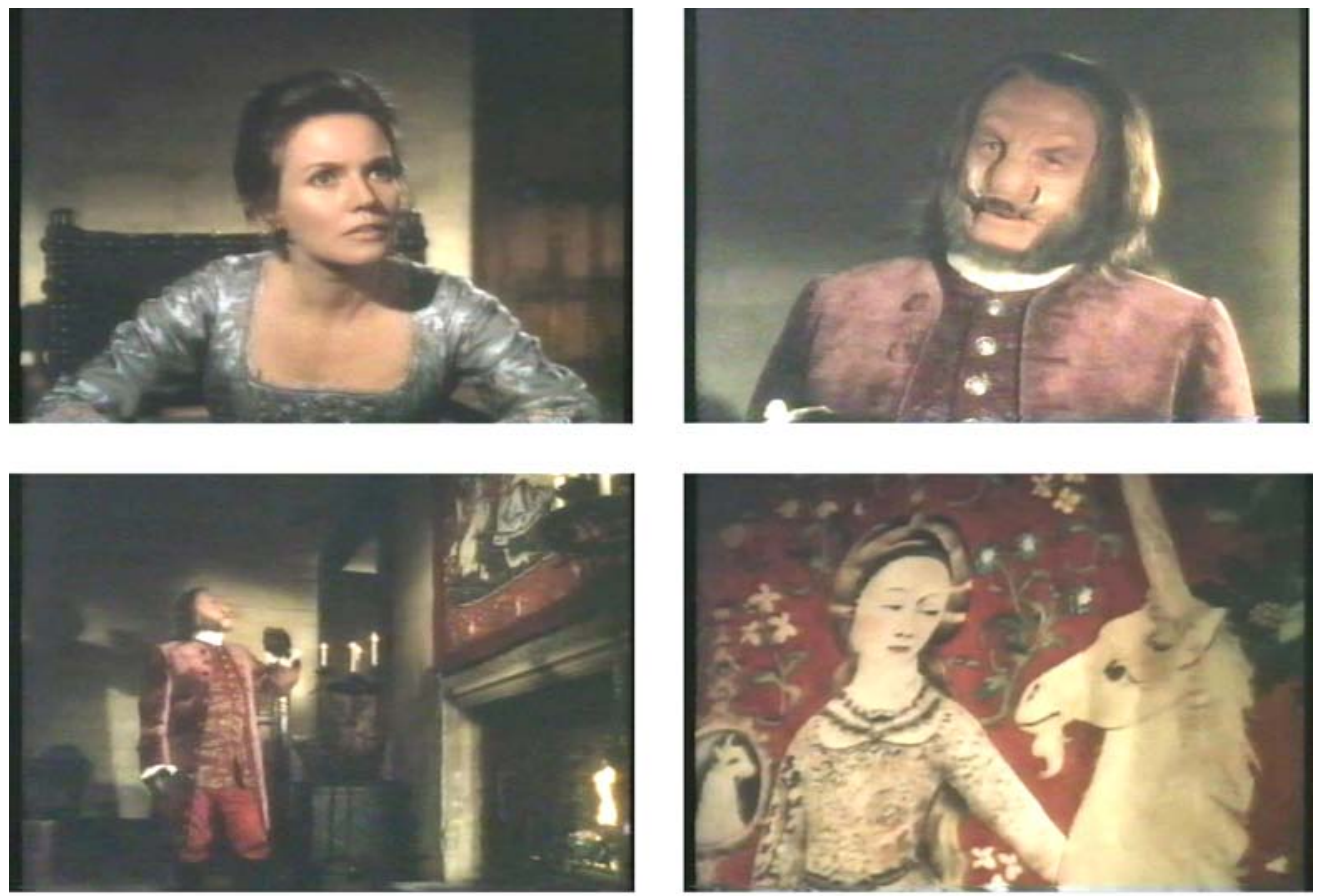

1. Secuencia de The Beauty and The Beast, dir. Fielder Cook, Hallmark Hall of Fame, 1976

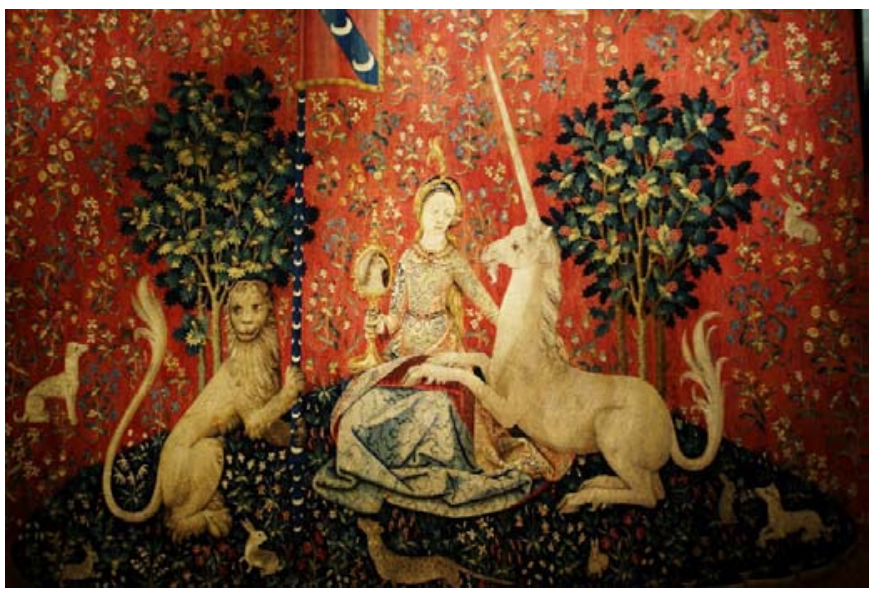

2. Anónimo. La dama y el unicornio (vista), tapiz, Museo Nacional de la Edad Media de París 
Cabe mencionar que esta no es la única referencia a lo salvaje o lo monstruoso, pues hay un momento en la película en que Bella quiere conocer a la Bestia, pero esta no le dice nada ni le responde. Así, vemos que cuando la joven llega a su cuarto encuentra un bestiario y allí empieza a conocer más sobre su anfitrión; es bastante particular, porque por las imágenes nos podemos dar cuenta de que es el libro de Ambroise Paré Monstruos y prodigios y de allí, podemos sacar la imagen de una bestia con pezuñas (fig. 3) así como esta bestia. No obstante, existe una ilustración realizada por Walter Crane (siglo XIX) para el cuento de la Bella y la Bestia (fig. 4), la cual inspiró la imagen del monstruo de esta versión fílmica.
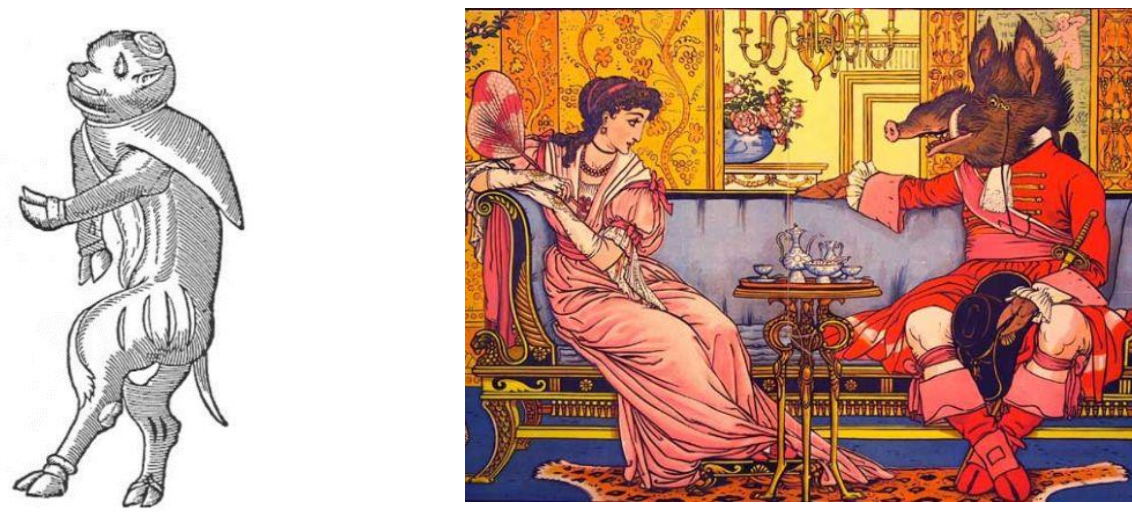

3. Derecha: Monstruo muy repulsivo, con manos y pies de buey, u otros detalles harto monstruosos. Tomada del libro de Amborise Pare, Monstruos y prodigios, España, Ediciones Siruela S. A., 1987. pág. 47 Izquierda: Ilustración de Walter Crane, siglo XIX

Por otra parte, para 1984 en la serie de televisión Fairy Tales Theatre, estrena un episodio titulado The Beauty and The Beast; la Bella es interpretada por Susan Sarandon y la Bestia es interpretada por Klaus Kinski. La historia presenta varios de los elementos del relato original, como el padre que sale de viaje en busca de una mercancía y se pierde en el camino encontrándose en un gran castillo mágico, donde es atendido. Luego, al tomar una flor para su hija menor, este es castigado por la Bestia, quien es el dueño del castillo y finalmente, para salvar a su padre, Bella termina viviendo con la Bestia. En cuanto a los elementos estéticos, esta versión retoma algunos elementos de la de Cocteau: el vestuario, las manos y brazos en movimiento como representación de la magia del castillo e incluso la apariencia de la Bestia (fig. 5), lo que demuestra que aún se tiene en la mente la historia o por lo menos el referente a la familia Gonsalvus.

Además, hay que señalar que al final de la película, la Bestia, una vez transformada en príncipe, le cuenta a la Bella, que él fue maldecido por un hada, ya que sus padres no creían en los cuentos de hadas y, por ello, el hechizo solo se rompería si una doncella se llegaba a enamorar de la Bestia. De esa manera, observamos que la transformación, dependía de un error de los padres y que el hijo debió asumirla; esto lleva a la relación moral donde la apariencia tiene que ver con el comportamiento, en este caso, el de los padres. 

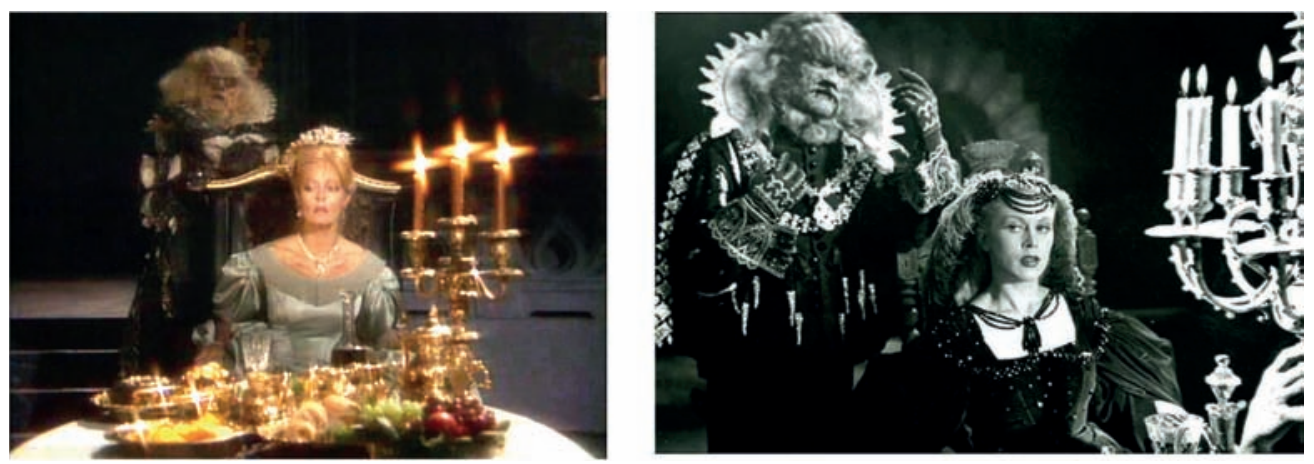

5. Derecha: La Bestia llegando al comedor para estar con la Bella, The Beauty and The Beast, dir. Roger Vadim, Playhouse Home Video, 1984. Izquierda: La Bestia llegando al comedor para estar con la Bella, La Belle et la Bête, dir. Jean Cocteau, DisCina, 1946.

Por otra parte, Mordicai Gerstein en 1988 estrena su versión de The Beauty and The Beast, basado en un libro que él mismo ilustró; así, el director nos va contando la historia de la Bella y la Bestia, narrada por Mia Farrow, mostrando a una bestia de un aspecto más diabólico, con unos cuernos pequeños que salen de su nariz y otros que salen de su cabeza, que tienen aspecto de cabra; pese a este aspecto tan espantoso, Gerstein nos muestra que la Bestia parece ser inofensivo y siente vergüenza por la doncella, que ahora vive en el palacio. Y es bastante particular cómo se va desarrollando el proceso en que la Bella civiliza a la Bestia a la par de su enamoramiento. Así, la apariencia de esta Bestia probablemente sea una de las representaciones más monstruosas que haya tenido hasta el momento ${ }^{18}$, pero eso tal vez se deba a tratar de buscar otro estilo de representación, para representar lo desconocido o lo extraño. Aunque, en apariencia esta criatura pudiera desgarrar a la doncella con mucha facilidad, vemos que es igual de dócil a un unicornio, pues se muestra inofensivo ante la presencia de aquella mujer y, aunque innumerables veces en el transcurso de la historia, Bella le pregunta a la Bestia por qué no la asesina, y vemos a un ser totalmente bueno, cuyo único objetivo es complacer a la doncella.

En 1991, Kirk Wise y Gary Trousdale, llevan a Disney su versión de The Beauty and The Beast. La secuencia inicial nos muestra un bosque y un palacio en el fondo, poco a poco por medio de acercamiento, con varios fundidos encadenados dirige la vista del espectador a unos vitrales, mientras la voz del narrador va contando la historia de cómo un joven príncipe rechazó dar posada a una anciana, en una noche de invierno. Así, por su arrogancia y por mirar las apariencias, fue castigado por la anciana quien era una hermosa hechicera, convirtiéndolo en una bestia (fig. 6); al final el narrador hace la pregunta "¿Quién podría algún día amar a una bestia?

18 Hay que tener en cuenta, que pese a que en las anteriores representaciones de la bestia, tienen una apariencia monstruosa a la vez, había rasgos en su rostro u ojos, que denotaban la ternura y compasión. Así, en este caso es la primera vez, que no dejan ningún indicio externo, de la nobleza que puede poseer la Bestia, que solo con su forma de actuar podemos percibir su timidez y simpatía. 

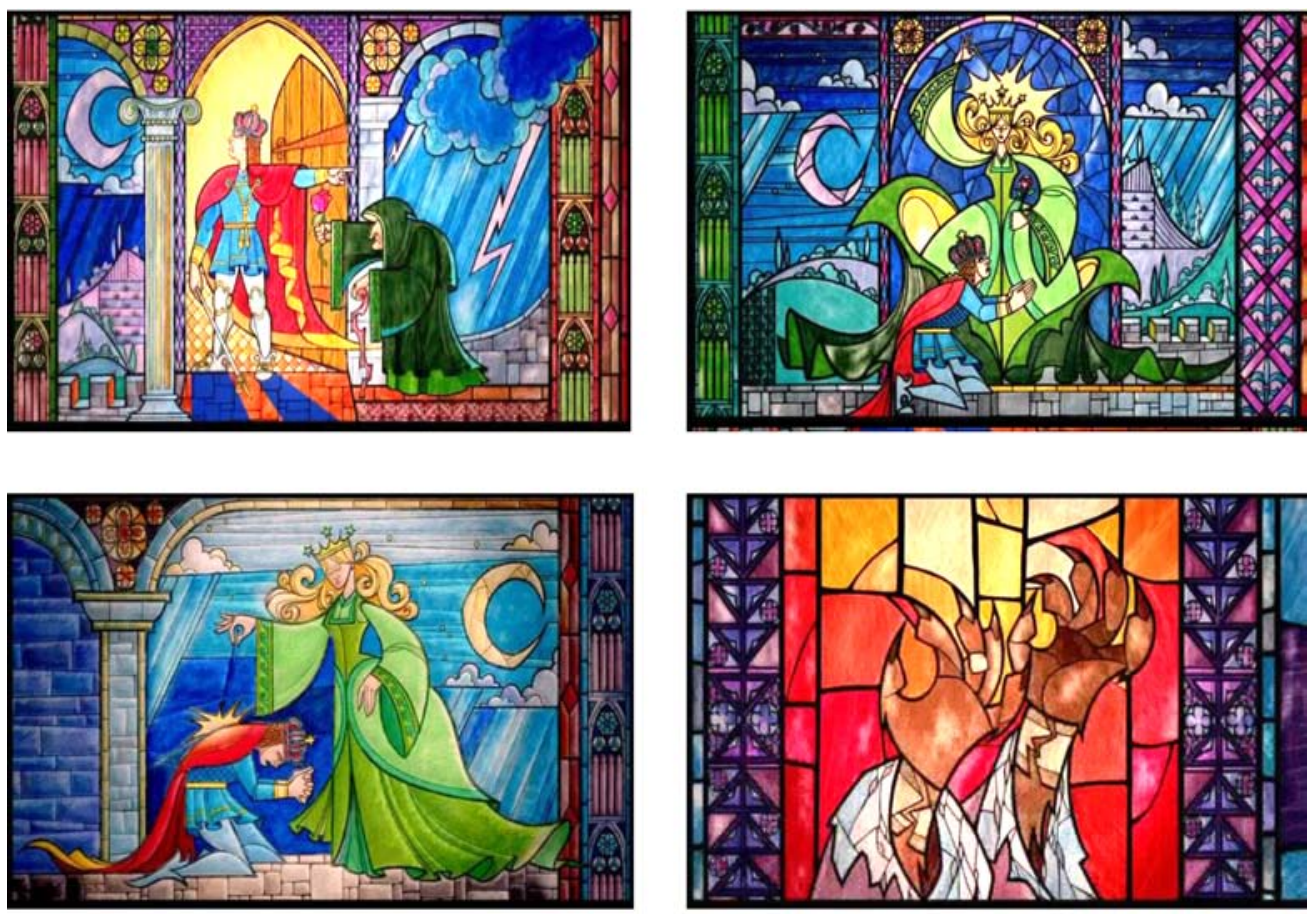

6. Secuencia de incio de The Beauty and The Beast, dir. Kirk Wise y Gary Trousdale, Walt Disney, 1991

De esa forma, a lo largo de la película, observamos cómo la Bestia tiene comportamientos salvajes y es muy temperamental, pero la Bella va civilizando a la Bestia e inculcándole costumbres y buenos modales; incluso, en la versión para DVD de la película, se añade una escena donde la Bella le lee a la Bestia la historia de Romeo y Julieta, y él quiere volver a escucharla, pero la joven dice que la lea él esta vez, pero la Bestia no sabe leer, o por lo menos dice que no toca un libro hace años, y así es como la Bella le enseña a la Bestia a leer. Así, esta película demuestra no solo la magia que puede haber en el castillo ${ }^{19}$, sino desde la convivencia de la joven con el monstruo, es como puede llegar a conocerlo realmente, para romper el hechizo, y de esa manera, ser ella quien ame a la Bestia.

\section{Érase una vez, un cuento al revés}

Las adaptaciones del cuento de la Bella y la Bestia no solo se dedican a seguir la historia original, sino que también existen versiones cinematográficas en donde los personajes ingresan a otras historias, como en el caso de The Beauty and The Beast de 1960 en Fractured Fairy Tales. Allí, vemos a una bestia de color azul, y peluda, que busca transformarse en príncipe, y para ello, cortésmente pide a las damas con quienes se encuentra que le den un beso; sin embargo, debido a su aspecto, solo recibe golpes, portazos y puñetazos.

\footnotetext{
19 En el caso de los sirvientes transformados en objetos o como cuando llega Bella al castillo, que Lumieré le da una bienvenida a lo Broadway, mientras presenta a toda la vajilla.
} 
Y, aunque la Bestia es civilizada, sigue recibiendo el rechazo de la sociedad por su aspecto. Lo más particular de esta versión es que se mezclan otros cuentos, para mostrar todo lo que puede llegar a hacer este monstruo para tener un aspecto apuesto. Así, lo podemos ver entrando por una chimenea como Papá Noel o escalando una enredadera, para llegar a Julieta que está en el balcón (fig. 7), pero él no logra conseguir su objetivo, y solo es al final, cuando llega una joven llamada Bella, quien le da el tan anhelado beso sin poder lograr cambiar de apariencia, cuando demuestra que esa es su verdadera apariencia y que él es el príncipe de los monstruos.
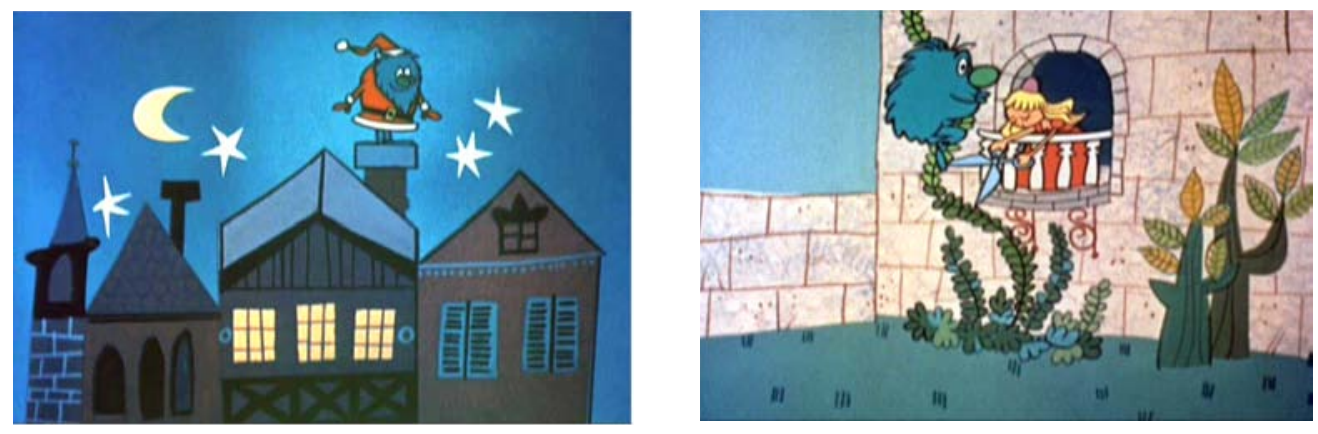

7. Derecha: La Bestia entrando por una chimenea disfrazado de Papá Noel, The Beuty and The Beast, dir. Gerard Baldwin (et al.), Jay Ward Productions, 1960. Izquierda: La Bestia subiendo por una enredadera para llegar a Julieta, The Beuty and The Beast, dir. Gerard Baldwin (et al.), Jay Ward Productions, 1960.

Para ese mismo año, la serie Fractured Fairy Tales estrena otra versión del cuento títulado The Beauty and Her Beast, donde narra la historia de una joven doncella que es fea y que al subirse a una mula encantada, se vuelve una mujer hermosa. Ella se casa con un príncipe, pero nunca puede bajarse de la mula, porque así se enterarán de su secreto. Entonces, un día ella decide bajarse para descansar y en ese momento se encuentra con el príncipe, quien descubre su secreto y le dice que él también pasa por la misma situación, así que, al bajarse del caballo le muestra a su esposa, que él tiene un aspecto horroroso al igual que ella y ambos deciden vivir felices así (fig. 8). En este caso, el elemento paródico le da un gran giro a la historia, porque no solo es inversión de los personas, ya que desde el comienzo de la historia la doncella es repugnante, sino que al final, el espectador se da cuenta de que son ambos, tal como sucedería más adelante en una película Shrek del 2001, donde la joven doncella es hechizada, y se convierte en las noches en una ogresa y que termina enamorándose de quien la rescató, Shrek, un ogro de muy mal humor ${ }^{20}$.

20 Aunque esta película como tal no se desprende como tal del cuento de la Bella y la Bestia, Jack Zipes la considera como una adaptación cinematográfica, llena de inversiones, sátira y critica a la versión de la Bella y la Bestia de Disney. 

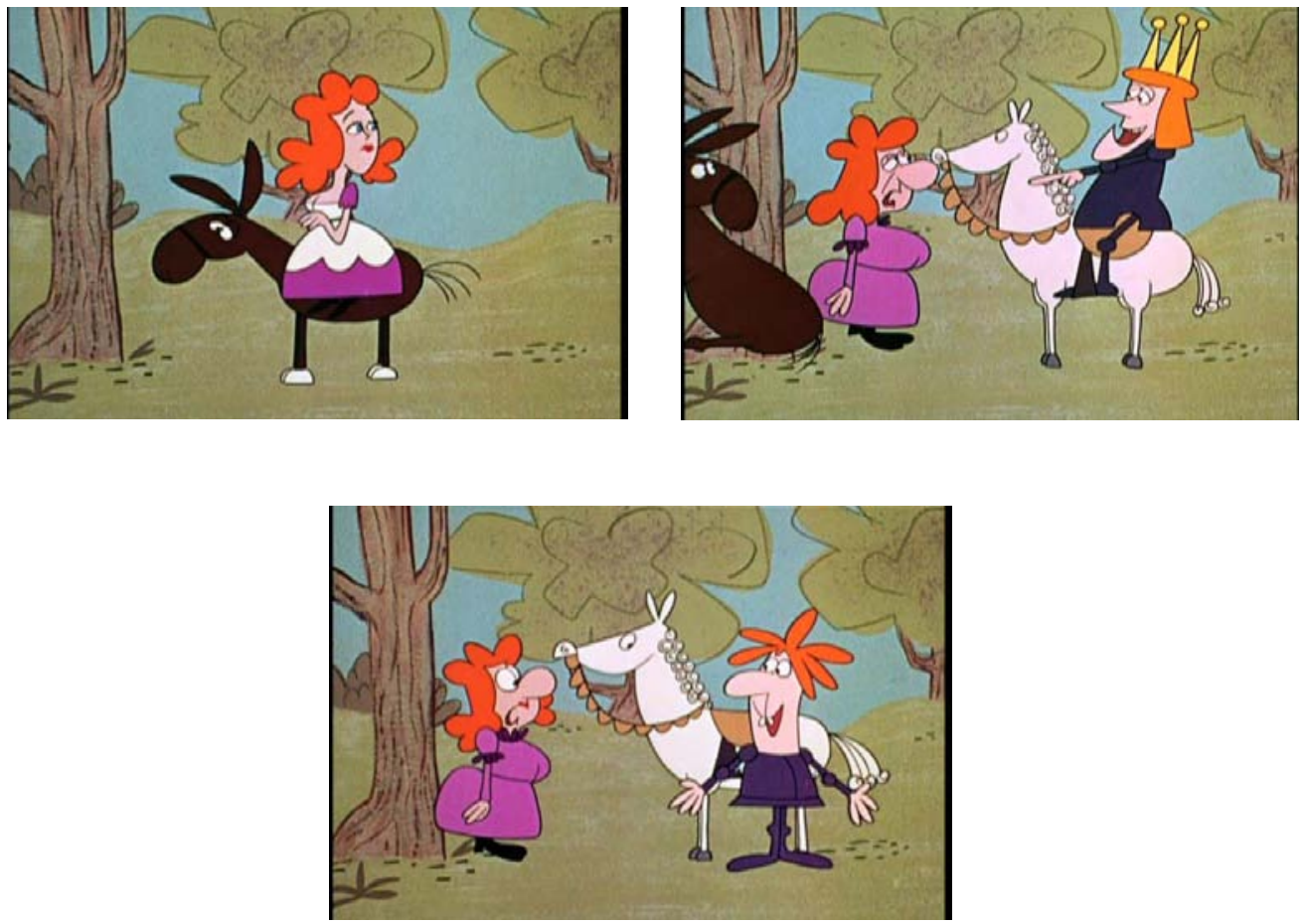

8. Secuencia de The Beauty and Her Beast, The Beuty and The Beast, dir. Gerard Baldwin (et al.), Jay Ward Productions, 1960.

En estas dos adaptaciones cinematográficas logramos ver cómo la sociedad juzga por las apariencias, ya que en las versiones analizadas, observamos cómo por su apariencia de hombres salvajes, los monstruos son tratados y vistos como animales; sin embargo, encuentran al final alguien que los comprenda o los entienda, para poder concluir su tránsito, viaje o rito del mundo animal al mundo civilizado. De modo que el problema en esta dicotomía es la mirada de la sociedad la que determina el proceso de separación o cercanía que tiene con el otro; pero cabe resaltar que, en estas historias como se dijo anteriormente, ese hombre salvaje es aceptado al final en la cultura.

Por otra parte, cabe destacar que estas versiones, de una u otra forma, hacen referencia a la civilización y a la barbarie, vistas desde el comportamiento de los dos protagonista y, en cierto modo, todas esas características apuntan a una relación entre la naturaleza y la cultura.

\section{Detrás de la historia de la Bella y la Bestia}

A lo largo de la historia, el hombre ha utilizado las clasificaciones para ordenar la naturaleza y el mundo que lo rodea con el fin de conocer, separar, jerarquizar y regular las relaciones con el medio y la sociedad. Por todo lo anterior, parecería que la cultura ha enseñado al 
hombre a tener un pensamiento muy simple: "todo lo que no es grande, es pequeño, todo lo que no es macho es hembra, todo lo que no es hombre es animal" (Cyrulnik, 1995, p. 128). De este modo, podemos observar cómo la sociedad se ha encargado de transmitir esas categorías, haciendo que el individuo actúe guiado por una serie de normas que se le imponen, dominando así su forma de pensar; por lo tanto, el sistema cristiano le ha impedido al hombre pensar en una prolongación entre el hombre y las bestias, como lo menciona Roger Bartra (2011). En ese sentido, el individuo posee un espíritu y razona y, así, por ejemplo, para una sociedad moralmente ceñida a reglas, no concibe el incesto, ya que esta le dice que está mal; en cambio "el mundo animal no conoce prohibición alguna" (Benveniste, 1985, p. 3).

En ese sentido, desde una mirada histórica, podemos encontrar que en el siglo XV, se creó y se popularizó el mito del hombre salvaje: un ser mitad hombre, mitad bestia, que se caracterizaba por tener excesivo vello en todo su cuerpo y por vivir en los bosques. La figura de este hombre maravilló por mucho tiempo a la sociedad de élite y a la popular, hasta tal punto de dar paso rápidamente a una tradición oral y a su recreación en la literatura y el arte. Al mismo tiempo, este mito abrió paso posteriormente a otros mitos como el buen salvaje $^{21}$, que de hecho era imaginar un hombre en estado cero, es decir, conectado con su pulsión natural, que habita pacíficamente, sin jerarquías sociales, y que desconoce la violencia. Y el mito del caníbal, aquel hombre que se encontraba en el Nuevo Mundo, que era violento y se alimentaba de carne humana ${ }^{22}$.

Así, en esta clasificación ficcional de los mitos, podemos observar que este hombre salvaje solo llega a existir en la tradición oral, siendo un relato basado en un hecho fantasioso. Pero no por ello deja de resaltarse la relación entre las categorías de cultura y naturaleza, lo cual nos lleva a pensar en la forma en que son creados los estereotipos, donde las imágenes pueden tener elementos reales o elementos falsos, exagerar u omitir algunos detalles. De esta manera, observamos que dichos modelos suelen carecer de matices o estar determinados por la mirada de un individuo o una cultura, que a menudo tiende a distorsionar la imagen del otro. Por ello, tal vez no deberíamos de mirar tanto los esquemas, sino mirar más bien qué es lo que se entremezcla en esas categorías, observar con detalle cómo se elabora esa representación, es decir, "... cuando se produce un encuentro entre culturas distintas, lo más probable es que las imágenes que una hace de otra sean estereotipadas" (Burke, 2005, p. 158).

De ahí, que con la expansión de la imagen del hombre salvaje, observamos que un sinnúmero de historias fueron alimentando estos mitos y no hay que olvidar que para esta

${ }_{21} \quad$ El mito del buen salvaje es una historia construida por el hombre europeo, para definir la otredad de las sociedades no civilizadas; cabe mencionar, que para la creación de este mito, fue necesario mirar en la historia antigua y medieval para crear un relato con muchos significados y una gran riqueza alegórica. Para amplia más sobre el tema ver Bartra, R. (2011), El mito del salvaje. México: Fondo de Cultura Económica.

22 Para amplia el tema ver Chicangana-Bayona, Y. A. (2013) Imágenes de caníbales y salvajes del Nuevo Mundo: De lo maravilloso medieval a lo exótico colonial, siglos xv-xvii. Bogotá: Editorial Universidad del Rosario. 
época, la sociedad creaba todo tipo de representaciones extrañas para explicar lo que ellos no podían comprender. Es así como para el siglo XVI, aparecen los primeros retratos de una familia, que despertaría mucha polémica: las imágenes mostraban a un padre y a sus hijos que padecían de "la dolencia de la piel conocida como hypertichosis universalis congenita, que hacía que le brotara pelo en todo el cuerpo, incluidas las manos" (Manguel, 2000, p. 111) o también llamada sindrome de ambras o hipertricosis (fig. 1).

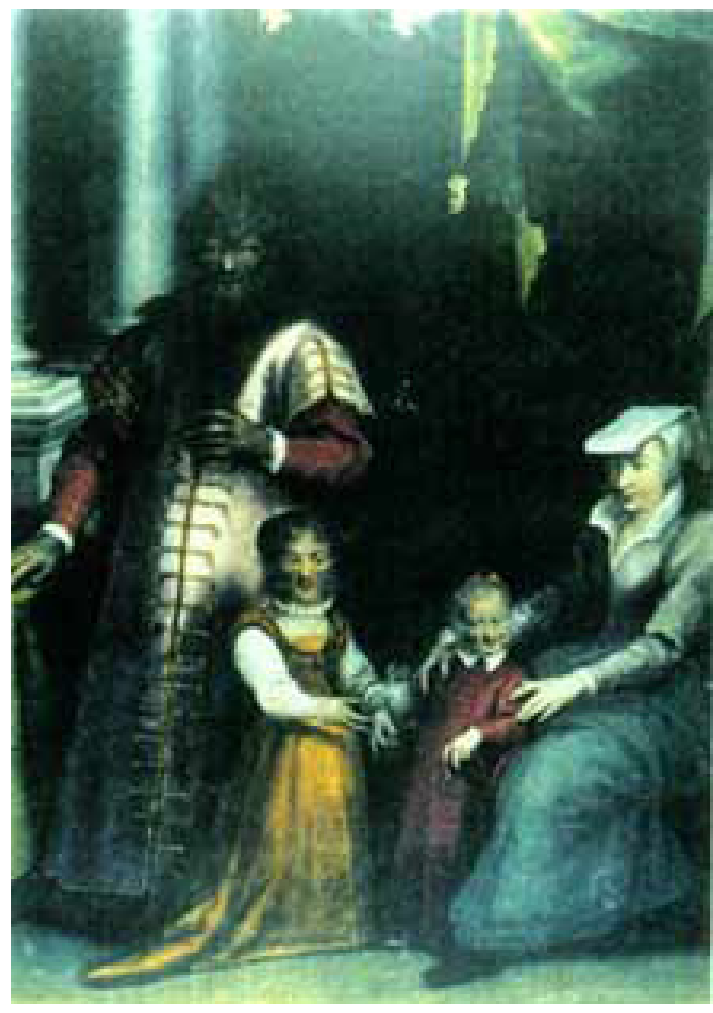

1. Dirk de Quade van Ravesteyn, La familia Gonsalvus, óleo sobre lienzo.

\section{Castillo Ambras en Austria}

Así, los miembros de la familia Gonsalvus se convertirían en seres humanos monstruosos o "errores de la naturaleza", como los denominó Rodolfo II en su catálogo, o "ejemplos de la ira de Dios", como menciona Ambroise Paré23. De esta forma, estos comentarios se debían a que los rasgos de animales que les proporcionaban el vello fácil hacían que se acercaran más a la naturaleza; sin embargo, los trajes elegantes y los emblemas de civilización le mostraban al espectador los rasgos de humanidad.

23 En el libro Monstruos y prodigios de Ambroise Paré, realiza un capitulo, donde explica las razones por las que "la ira de Dios" actúa para castigar a los pecadores y, de esa manera, el producto de esa condena es un niño monstruoso. 
Este caso en particular despertó la curiosidad y el miedo, a la vez, en su tiempo, ya que es un claro ejemplo del desvanecimiento entre lo que es animal y lo que es la cultura. Por ello, es fácil encontrar discusiones tan contradictorias en torno a esta familia; en este sentido, comprobamos cómo la mirada de un individuo o una sociedad expresa sus miedos y pensamientos con respecto a lo que no se conoce. Esto nos lleva a ver, que el caso de la familia Gonsalvus sirvió como fuente de inspiración para los cuentos de hadas ${ }^{24}$, que en cierto modo tratan este tema: Piel de asno (1694), de Charles Perrault o Piel de oso, de los hermanos Grimm (1857). A lo anterior, conviene distinguir que existe un cuento en particular que fue escrito en 1770 en Francia por Jeanne-Marie Leprince de Beaumont La Bella y la Bestia, que narra la historia de un mercader muy rico, que tiene seis hijos, tres hombres y tres mujeres que están muy acostumbrados a las riquezas, pero al caer en la desgracia, pasan a vivir al campo y la más joven de las hijas, apodada como "Bella", muestra que es una mujer capaz de encargarse de las labores de la casa, mientras sus hermanas no hacen nada en todo el día.

Un día el padre recibe noticias de una mercancía y se marcha para recibir su parte; a pesar de sus ilusiones, no consigue nada y decide volver a su casa, pero en el camino se extravía y llega a un castillo en el que lo atienden muy bien. Al final de su estadía, en el momento de partir, recuerda que su hija Bella le pidió que le llevara una rosa y tras cortarla, descubre que quien le dio el hospedaje fue una bestia, así que para abandonar el lugar le promete a la Bestia que volverá o en su lugar tendrá que venir una de sus hijas.

Es así como Bella pasa a vivir con la Bestia, quien al principio lo encontraba como un ser horrible, un animal, pero conforme pasa el tiempo con él, se da cuenta de que es diferente: "Hay muchos hombres más bestiales que tú — dijo la Bella—, y mejor te quiero con tu figura, que a otros que tienen figura de hombre y un corazón corrupto, ingrato, burlón y falso" 25 .

Es así, como se observa en el cuento que la Bestia, a pesar de tener la apariencia de un monstruo, tiene un buen corazón, mientras que las hermanas de Bella, que poseen una hermosa figura, son egoístas y malas. Es por ello que al final del cuento, la Bestia se transforma en un hermoso príncipe, mientras que las hermanas de Bella, se convierten en estatuas por el hechizo de un hada. Estas características hacen parte de la moraleja de historia, en la cual dejaría como enseñanza que las buenas obras cuentan, mientras que los malos actos son castigados; por ello, este relato no solo juega con la dualidad de la civilización/barbarie, sino que, a su vez, juega con la imagen del ejemplo.

\section{Consideraciones finales}

A modo de reflexión, considero que el cuento de la Bella y la Bestia es un buen ejemplo para analizar la dicotomía entre civilización y barbarie, ya que nos muestra cómo es la

24 Zipes, J. (2011) "Choosing The Right Mate: Why Beast And Frogs Make For Ideal Husbands", en: The Enchanted Screen: The Unknown History of Fairy-Tale Films. New York. Routledge. pp. 224-251

25 Leprince de Beaumont, J.M (1770). La bella y la bestia. Recuperado el 21 de octubre de 2013. Disponible en: http://www.ciudadseva.com/textos/cuentos/fran/leprince/la_bella_y_la bestia.htm 
mirada de la sociedad ante la interpretación y adaptación de ciertos elementos o características en el lenguaje cinematográfico, demostrando que no solo se queda esa discusión en la literatura, sino que pasa a ser representada en el celuloide, y que en cada una de estas versiones, recrea o retoma ciertas estructuras, de las cuales siempre surgen nuevos elementos, los cuales están vinculados a procesos de apropiación del cuento26.

Así, la historia del hombre salvaje en sus versiones nobles y benignas no solo se queda en esos mitos y cuentos, sino que queda ejemplificada en cierta forma en la figura de la bestia; por ello, vemos que en todas versiones analizadas la bestia es reintegrada a la sociedad luego de ser civilizada, pero cabría preguntarnos, ¿qué pasaría si esta fuera rechazada y aislada?

Para ello, debemos comprender que la Bella y la Bestia, tanto en cuento como en versiones cinematográficas, inspiraron la creación de otras versiones. Y aunque estas se asemejan, al tener en su discurso como protagonistas a una doncella y un monstruo, lo que las diferencia son los elementos del rechazo y el aislamiento; por ello, en películas como El gabinete del Dr. Caligari (1920), Frankenstein (1931), King Kong (1933) y Edward Scissorhands (1991), observamos la estructura de un individuo salvaje que trata de ser incluido en la sociedad, pero termina siendo rechazado por esta. Y, en el final, sufre el trágico destino de volver a su torre de marfil —en el caso de Edward — o ser asesinado. Cabe mencionar que en el caso de El hombre manos de tijeras, la historia nos recuerda mucho a la de Víctor de l'Aveyron ${ }^{27}$, quien fue uno de los casos más famosos de niños salvajes, ya que a este niño se le trato de enseñar las costumbres de una sociedad, él las aprendió pero sufrió mucho en el proceso, porque estaba acostumbrado más a las normas de su medio salvaje, y por ello, volvió a su bosque, al lugar donde pertenecía.

Por esta razón es fácil comprender cómo aún la sociedad esta fascinada por la relación entre la naturaleza y la cultura, y cómo la historia de la Bella y la Bestia cautivó el imaginario de la cultura, para replicar una y otra vez la imagen del salvaje, para poder codificar entre líneas el miedo a lo desconocido, a ese otro que en este caso es representado como el monstruo. Y todo ello con el fin de poder buscar una forma de definirse a sí mismo a través de una imagen que es repulsiva pero a la vez atractiva, para poder construir así una imagen del otro, haciendo que esa alteridad nos cause curiosidad y nos maraville.

\section{Fuentes:}

\section{* Cuento:}

Leprince De Beaumont, J. M. (1770) "La bella y la bestia" Recuperada el 21 de octubre de 2013. Disponible en http://www.ciudadseva.com/textos/cuentos/fran/leprince/la_bella_y_la_bestia.htm,

26 El proceso de adaptación tiene varias etapas como la (re) interpretación y la (re) creación de elementos para poder nuevos puntos de vista de una historia. Para ampliar el tema ver Hutcheon, L. (2013) A Theory of Adaptation. New York. Routledge.

27 Niño salvaje encontrado en 1799, en una región de Francia y educado por el doctor Jean Itard. De este mismo caso se elaboró una película titulada "El pequeño salvaje" que está basada en los apuntes del diario del Dr. Itard, mostrando visualmente la adaptación y sufrimiento por lo que tuvo que pasar Víctor. 


\section{* Filmografía:}

\section{Cortometraje:}

Gerard Baldwin (et al.), Beauty and Her Beast, Jay Ward Productions, (1960).

Gerard Baldwin (et al.), Beauty and The Beast, Jay Ward Productions, (1960).

\section{Mediometraje:}

Mordicai Gerstein, Beauty and the beast, Lightyear Entertaiment, (1990)

Roger Vadim, Beauty and the Beast, Playhouse Home Video, (1984)

\section{Largometraje:}

Fielder Cook, Beauty and The Beast, Hallmark Hall of Fame, (1976)

Kirk Wise y Gary Trousdale, Beauty and the Beast, Walt Disney, (1991)

\section{Bibliografía}

Bartra, Roger (2011), El mito del salvaje. México: Fondo de Cultura Económica.

Benveniste, Émile (1971), Problemas de lingüística general. México: Siglo XXI editores.

Borja Gómez, Jaime Humberto (2002). "El exemplum en la narración histórica", en Los indios medievales de Fray Pedro de Aguado. Construcción del idólatra y escritura de la historia en una crónica del siglo XVI, Bogotá: CEJA, pp.167-174.

Burke, Peter (2005), "Estereotipos de los otros", en Visto y no visto. El uso de la imagen como documento histórico. Barcelona: Crítica, pp. 155-175.

Berberi, Tammy y Berberi, Viktor (2013), "A Place at the Table: On Being Human in the Beauty and the Beast" en Cheu, Johnson. Diversity in Disney Films. Critical Essay on Race, Ethnicity, Gander Sexuality and Disability. Estados Unidos: McFarland \& Company.

Chicangana-Bayona, Yobenj Aucardo (2013) Imágenes de caníbales y salvajes del Nuevo Mundo: De lo maravilloso medieval a lo exótico colonial, siglos XV-XVII. Bogotá: Editorial Universidad del Rosario.

Cyrulnik, Boris (2004), "La bella y las bestias", en: Del gesto a la palabra. La etología de la comunicación en los seres vivos, España: Editorial Gedisa, pp. 38-45.

Darnton, Robert (1987). "Los campesinos cuentan cuentos: El significado de mamá oca", en La gran matanza de gatos y otros episodios en la historia de la cultura francesa, México D. F: Fondo Cultura Económica, p.p. 15-80

Douglas, Mary (1996). "Los usos de la divulgación: una lectura francesa de Caperucita Roja" en Estilos de pensar, España: Gedisa, pp. 19-37.

Eco, Umberto (2010). Historia de la belleza, Barcelona: Debolsillo.

Eco, Umberto (2011). Historia de la fealdad, Barcelona: Debolsillo.

Ginzburg, Carlo (1991), "Huesos y pieles", en Historia nocturna un desciframiento del aquelarre, España: Muchnik Editores S. A., pp. 173-213

Hutcheon, Linda (2013), A Theory of Adaptation, New York: Routlege.

Kappler, Claude (1986), Monstruos, demonios y maravillas a fines de la Edad Media, Madrid: Akal.

Lévi-Strauss, Claude (1998), "La ciencia de lo concreto" en El pensamiento de salvaje. México: Fondo de cultura económica, pp. 11-59. 
Lévi-Strauss, Claude (1988). "Las tres fuentes de la reflexión etnológica". En La antropología como ciencia. Barcelona: Anagrama, 1988.

Manguel, Alberto (2000), "La imagen como comprensión", en Leyendo imágenes. Una historia privada del arte. Colombia: Editorial Norma, pp.105-136.

Paré, Ambroise (1987). Monstruos y prodigios, España: Ediciones Siruela S. A.

Rousseau, René-Lucien (1994), "Tabúes y mitos admonitorios", en La otra cara de los cuentos. Valor iniciático y contenido secreto en los cuentos de hadas. Gerona: Tikal Ediciones, pp. 131-153.

Zipes, Jack, "Choosing The Right Mate: Why Beast And Frogs Make For Ideal Husbands", en The Enchanted Screen: The Unknown History of Fairy-Tale Films. New York. Routledge. 2011. pp. 224-251.

Zipes, Jack (2014), El irresistible cuento de hadas. Historia cultural y social de un género, Buenos Aires: Fondo de Cultura Económica. 